\title{
Internal Corporate Communication and Job Performance: A Comparative Study of Public and Private Telecom Organizations
}

\author{
Dr Ajai Kumar Jain ${ }^{1}$, Devika Trehan ${ }^{2}$ \\ ${ }^{1}$ Senior Assistant Professor, Institute of Management Studies, Devi Ahilya Vishwavidyalaya, Indore. \\ ${ }^{2}$ Research Scholar, Institute of Management Studies, Devi Ahilya Vishwavidyalaya, Indore
}

\begin{abstract}
In modern corporate organizations which are characterized by diverse workforce the leaders and managers need to communicate with them constantly and consistently for better job performance. This primary research aims to explore the impact of internal corporate communication satisfaction on job performance. Random convenience sampling was used to collect the data from employees of public and private telecom sector organizations based in Indore India. The data from 605 employees were processed by using Statistical Package for the Social science (SPSS) and MS EXCEL software. Independent sample t-test and linear regression were used to analyse the data. The study concluded differently from previous studies as organizational integration and organizational perspective have emerged as two very important dimensions influencing the job performance.
\end{abstract}

Keywords: Job performance, Internal communication satisfaction, Public sector, Private sector

\section{Introduction}

Today's work environment has transformed into a culturally diverse work environment. With this all inclusive nature of today's organizations it has become difficult for the leadermanagers to manage the workforce. Hence, to manage this diverse workforce the employers need to communicate with them constantly and consistently. Therefore, employers are conducting communication based activities which are extremely important for the health of the organization and that shall yield handsome returns in the future. Bearing in mind that the services industry is highly people intensive, the quality and quantity of the workforce is a major contributor to the revenue of the organization, in such a situation strong internal communication, and human resource practices become key devices (De Chernatony and Horn, 2003; Thite, 2004; Domenec, 2012).Human capital has come to be recognized as the bread winner and a source of value for businesses and shareholders. The talent today looks at the external and internal communication practices of the organization and the refining of these, signals to the potential talent about the complete employee experience there. As talent is uncommon, appreciated, tough and hard to replace and organizations that are able to better choose, charm and hold this talent they outdo those that do not (Barney and Wright, 1998).Welch and Jackson's extensive review of works in the area of public relations by Grunig, corporate communication by van Riel and organizational communication by Cheney and Christensen and concluded in defining internal communication as: "the strategic management of interactions and relationships between stakeholders at all levels within organizations" (Welch \& Jackson, 2007). The pioneer research in performance measurements were conducted during 1950 - 1960 in the military division in Californiametais (Zimmermann and Stevens, 2006). "Job performance can be defined as a person's ability to perform his/her job effectively" (Giri and Kumar, 2010).

\section{Objectives of the Study}

a) To examine the level of satisfaction with ICC can impact employee job performance in public and private sector telecom organizations.

b) To examine the dimensions of internal corporate communication which have a strong impact on job performance.

c) Despite the relationship between communication and performance, yet, it is not been given the due attention, has the scenario changed or still remains the same?

d) Understand the role that internal communication shall play in enhancing employee job performance.

\section{Review of Literature}

The foremost objective of internal communication is to inform the workforce about their tasks and the policy issues of the organization (Francis, 1989; De Ridder, 2003). The second goal is to construct a community within the organization (Francis, 1989; Postmes et al., 2001; De Ridder, 2003). The community of internal stakeholder groups that comprise of all employees, strategic management, day-to-day line management, work teams, and project teams (Grunig, 1992; van Riel, 1995; Cheney \& Christensen, 2005).

Van Riel designates internal communication as a component of organisational communication, within his overall cohesive corporate communication model (van Riel, 1995). It is understood as employee communication and relates it to the process of communication with supervisors and colleagues (Smidts et al., 2001). Described internal communication in the framework of the corporate communication function (Dolphin, 2005). Internal communication impacts the degree of empathy employees feel with their organisation and their approach to support the organisation (Edwards, 2009). Likewise, Fay expounds that internal communication functions to satisfy the need of 


\section{International Journal of Science and Research (IJSR) \\ ISSN (Online): 2319-7064}

Index Copernicus Value (2015): 78.96 | Impact Factor (2015): 6.391

belongingness of and bonds the individual to their organisation (Fay, 2011). The concept of communication has been set in the literature in numerous ways. Communication is proposed to be a holistic concept encompassing of dialogue and verbal signs thereby creating an exchange process (Hoben et al., 2007), communication is a procedure when the constituents' comprehend each other (Kekelis\& Andersen, 1984).

In general parlance, terms such as profit and turnover are used to determine productivity and terms like supervisory ratings, goal accomplishments are in use to determine performance, efficiency and the perception approach. The factors linked with performance are not universal and vary between different managerial levels and nature of the organizations (Downs \&Hain, 1981). Though certain performance parameters are common such as quality of work, quantity of work, time taken to accomplish the task, are seen in the evaluation criteria of large corporations (Downs \&Moscinski, 1979). Job performance and job satisfaction are multidimensional constructs (Downs \&Hain, 1981).

\section{Internal Communication and Its Measurement}

To understand the holistic picture both the direction (information flow) and perception (employees' perceptions and attitudes) aspects of ICC have to be measured (Pincus, 1986; Gray\& Laidlaw, 2002). The most commonly used survey instrument to map communication satisfaction is the Communication Satisfaction Questionnaire developed by Downs and Hazens consisting of eight dimensions and the ninth dimension in this model was added by Pincus revalidated by Clampitt and Downs (Downs \& Hazens 1977; Pincus, 1984; Clampitt and Downs, 1990). CSQ is a multidimensional construct comprising of "Personal feedback Information concerning how workers are being judged and how their performance is being appraised" (Downs \& Hazens, 1977). "Organizational integration is a dimension of ICC satisfaction which focuses on the extent to which employees receive information about their immediate work environment" (Downs \& Hazens 1977). "Horizontal communication measures the degree to which horizontal and informal communication is accurate and free flowing" (Downs \& Hazen 1977). "Subordinate communication concerns with the openness of individuals to downward communication and their receptiveness and potentiality to send information upward" (Downs \& Hazen 1977). "Organizational perspective provides the information about the organisation as a whole which includes notifications about changes, overall policies, and goals of the organisation" (Downs \& Hazen 1977). "Supervisory communication encompasses both the upward and downward facets of communicating with supervisors" (Downs \& Hazen 1977). "Media quality is related with the extent to which meetings are well organized and written directives are short and clear" (Downs \& Hazen 1977)."Communication climate discusses the extent to which communication in an organization motivates and stimulates workers to meet organizational goals" (Downs \& Hazen 1977). "Top management communication is the extent to which informal communication is accurate and free flowing, with the top management" (Pincus, 1986).

\section{Internal Communication and Job Performance}

It has been researched that constructive internal communication has seen to have a direct impact on leading to a surge in job satisfaction and employee performance (Jain, 1973; Hellweg \& Phillips, 1980; Downs \&Hain, 1982; Camden \& Witt, 1983; Papa \& Tracy, 1987; Snyder \& Morris, 1984;Jo \& Shim 2005;Watson Wyatt study, 2005/2006; Chuang and Hsieh, 2009; Giri\& Kumar, 2010; Udegbe et al, 2012). Some scholars presented positive results that concluded that supervisor communication, internal managerial communication (Tubbs \&Hain, 1979), lateral communication, communication climate, personal feedback, Communication channelswere found to be most strongly related to job performance (Jain 1973;Pincus, 1986; Clampitt \& Downs, 1993; Hargie et al., 2002; Mung'ora et al., 2014). A good organization communication climate support the employee's performance better (Masmuh, 2010). Communication dimensions with the maximum support as predictors were accuracy of information, desire for interaction, communication load, trust in superior, influence of superior, and satisfaction with communication (Pettit et al., 1997).Research shares employees build effective work relationships when their needs are being met with effective internal communication (Gray\& Laidlaw, 2004). Scholars note that effective and satisfactory communication may contribute to an organization's productivity, performance, and external customer orientation (Hargie\&Tourish 2000; Downs \& Adrian, 2004; Zwijze-Konig\& de Jong, 2007). Effective communication between co-workers in an organization leads to efficient allocation of human resources, and in turn, higher productivity (Agarwal, 2006). A study of 397 employees of an insurance company that individual with high growth needs and performing difficult jobs within organic (i.e., open communication) organizational units exhibited top levels of performance and satisfaction (Pierce et al., 1979)."Constant feedback by a manager on employee performance plays a crucial role in the design of supportive working environments and cooperative teams and on improving the performance quality" (Gratton, 2008). When specific and flawless job instructions as well as correct performance feedback are provided to subordinates they find it easier to attain goals. (Raina \& Roebuck 2014). The study conducted in small and large manufacturing and service organizations revealed that communication supports in achieving organizational goals, a significant relationship was found between communication and performance, however the level of impact varies from one organization to another (Udegbe et al, 2012).

There also have been studies that found no substantial relationship between perceived downward communication and job performance and result in demoralize employees resulting decline in performance(Anderson \& Level, 1980; Mung'ora et al., 2014). Another study concluded that there is no clear contribution of communication in enhancing employee performance (Pettit et al., 1997). Another research by Rodwell, Kienzle\&Shadur (1998) among IT employees establish that teamwork, job satisfaction and communication 


\section{International Journal of Science and Research (IJSR) \\ ISSN (Online): 2319-7064}

Index Copernicus Value (2015): 78.96 | Impact Factor (2015): 6.391

are positively related but communication was found to be negatively related to performance. There have been research work focussing on understanding the impact of perceived communication on the five parameters influencing the overall performance of the organization, which did not yield very promising results. However, dimensions such as quality of supervisory communication and information exchange within peer workgroups were found to have a substantial association with profits and performance (Snyder \&Morris, 1984). Even though it seems undisputable that communication is vital for organization's functioning and consequently affects its earnings which at a singular level relates to employee's performance, academic propositions are not reinforced by practical findings and there are debateable issues in definitions, measurement as well as the scarce research in the field.

Analysis of data highlights that still in various PSUs, the development of full-fledged CC departments is still at a budding stage; at the same time in some PSUs progress of $\mathrm{CC}$ is already reorganised with company vision and is established as a division. Strategic acceptable PR roles include communication for creating desired image and opinion among target audience and brand sustainability. In established CC departments, CC is a strategic management tool, synchronizing all intentional forms of internal and external communications, thus helping the PSUs to define its corporate image and improve corporate performance. Through the built-in measurement systems, PSUs are encouraged to become global players (SarojKoul 2009). In private organizations, $\mathrm{CC}$ has been working under different names and guises, but in the last few years it has been given its due share but is yet to find a seat at the table of the board of directors to take CC to the strategic level. Recent studies point that employee relationships and communication networks within an organization are key to organizational performance. With the research evidence it is very coherent that internal communication satisfaction enhances the sense of achievement of an employees, which in turn motivates them to work hard to achieve their goals and hence impacting their performance and productivity. Sparse research work in the area of evaluation of job performance and equally weak research in how, when, why and where does internal corporate communication in its different forms impacts job performance (Hellweg \& Phillips, 1980) have led to the following hypothesis:

$\mathrm{H}_{1}$ : There is no significant difference in the levels of ICC satisfaction amongst public and private telecom sector organizations.

$\mathrm{H} 2_{0 \text { : }}$ There is no significant difference in the levels of job performance in public and private telecom sector organizations.

$\mathrm{H} 3_{0}$ : There is no significant impact of internal corporate communication on job performance in public and private telecom sector organizations.

$\mathrm{H} 4_{0}$ : There is no significant difference in the impact of internal corporate communication satisfaction in predicting job performance in public and private telecom sector organizations.

$\mathrm{H} 5_{0}$ :There is no significant impact of individual dimensions of internal corporate communication in predicting job performance in public and private telecom sector organizations.

\section{Research Methodology}

The research study was primary data based study using descriptive survey design for developing the questionnaire. Data collection was done through random convenience sampling method. Statistical tools used for answering the research questions are descriptive analysis, independent sample t-test and linear regression. Sample size - 605 employees from public and private sector telecom sector organizations. The sample consisted of $86 \%$ male and $14 \%$ female respondents. Majority respondents' were in the age bracket of 26-35 years 53\%. Majority of respondents had a basic graduation degree $60 \%$, the maximum population in the lower management level $54 \%$ with most of the employees having a min. tenure between up to 5 years for private sector $52 \%$ and 6 to 10 years $49 \%$ for public sector firms. Measurement- The relation between these two dimensions were investigated using the Communication Satisfaction Questionnaire (Downs and Hazen, 1977) with a Cronbach alpha coefficient of 0.95 and job performance using Work Performance Scale (Goodman \&Svyantek, 1999) with a Cronbach alpha coefficient of 0.81.

\section{Results and Findings}

$\mathrm{H} 1_{0}$ : There is no significant difference in the levels of ICC satisfaction amongst public and private telecom sector organizations.

Table 1: ICC Satisfaction Levels Pu/Pr Sector

\begin{tabular}{|c|c|c|c|c|}
\hline Items & T.Org & $\mathrm{N}$ & Mean & SD \\
\hline \multirow{2}{*}{ SC } & Private & 304 & 3.8103 & .63588 \\
\cline { 2 - 5 } & Public & 301 & 3.9264 & .61861 \\
\hline \multirow{3}{*}{ Sb.C } & Private & 304 & 3.5763 & .82244 \\
\cline { 2 - 5 } & Public & 301 & 3.7256 & .79836 \\
\hline \multirow{2}{*}{ CC } & Private & 304 & 3.5673 & .65621 \\
\cline { 2 - 5 } & Public & 301 & 3.6416 & .63052 \\
\hline \multirow{2}{*}{ OI } & Private & 304 & 3.7512 & .68000 \\
\cline { 2 - 5 } & Public & 301 & 3.7787 & .75798 \\
\hline \multirow{2}{*}{ MQ } & Private & 304 & 3.5258 & .67471 \\
\cline { 2 - 5 } & Public & 301 & 3.5775 & .76394 \\
\hline \multirow{2}{*}{ HC } & Private & 304 & 3.4297 & .55284 \\
\cline { 2 - 5 } & Public & 301 & 3.3239 & .54947 \\
\hline \multirow{2}{*}{ OP } & Private & 304 & 3.7822 & .85230 \\
\cline { 2 - 5 } & Public & 301 & 3.7920 & .87693 \\
\hline \multirow{2}{*}{ PF } & Private & 304 & 3.6224 & .72396 \\
\cline { 2 - 5 } & Public & 301 & 3.6804 & .71818 \\
\hline \multirow{2}{*}{ TMC } & Private & 304 & 3.5036 & .54744 \\
\cline { 2 - 5 } & Public & 301 & 3.4093 & .55327 \\
\hline
\end{tabular}

The null hypothesis stands accepted as the analysis indicates no significant difference in the overall satisfaction levels with internal corporate communication in public and private sector telecom organizations. The analysis reveals that in the public sector telecom organizations higher levels of satisfaction was reported with supervisory communication, organizational perspective, organizational integration and subordinate communication. In the private sector organizations reported higher levels of satisfaction with supervisory communication, organizational perspective, organizational integration and personal feedback. In the 


\section{International Journal of Science and Research (IJSR) \\ ISSN (Online): 2319-7064}

Index Copernicus Value (2015): 78.96 | Impact Factor (2015): 6.391

various ICC dimensions the public sector telecom employees reported higher levels of satisfaction with an exception of horizontal communication which shows a higher level of satisfaction amongst the private sector employees.

$\mathrm{H} 2_{0 \text { : }}$ There is no significant difference in the levels of job performance in public and private telecom sector organizations.

\begin{tabular}{|l|l|c|c|l|}
\hline & $\mathrm{TO}$ & $\mathrm{N}$ & Mean & $\mathrm{SD}$ \\
\hline \multirow{2}{*}{ Individual Performance } & Private & 304 & 3.7899 & .41209 \\
\cline { 2 - 5 } & Public & 301 & 3.9924 & .64310 \\
\hline
\end{tabular}

The null hypothesis is not accepted as the results of the ttest reveals that there is a significant difference between the levels of job performance between public and private telecom sector organizations. Public sector telecom organizations report higher levels of job performance as compared to private sector telecom organizations.

$\mathrm{H} 3_{0}$ : There is no significant impact of internal corporate communication on job performance in public and private telecom sector organizations.

Table 1: Impact of ICC on Job Performance Private Telecom Sector Organizations

\begin{tabular}{|c|c|c|c|c|}
\hline \multicolumn{5}{|c|}{ Model Summary } \\
\hline Model & $\mathrm{R}$ & $\begin{array}{c}\mathrm{R} \\
\text { Square }\end{array}$ & $\begin{array}{c}\text { Adjusted R } \\
\text { Square }\end{array}$ & $\begin{array}{c}\text { Std. Error of the } \\
\text { Estimate }\end{array}$ \\
\hline 1 & $.672^{\mathrm{a}}$ & 0.452 & 0.450 & 0.30551 \\
\hline a. & Predictors: (Constant), Corporate Communication \\
\hline
\end{tabular}

\begin{tabular}{|c|c|c|c|c|c|c|}
\hline \multicolumn{7}{|c|}{ ANOVAa } \\
\hline \multicolumn{2}{|c|}{ Model } & $\begin{array}{c}\text { Sum of } \\
\text { Squares }\end{array}$ & df & $\begin{array}{c}\text { Mean } \\
\text { Square }\end{array}$ & F & Sig. \\
\hline \multirow{3}{*}{1} & Regression & 23.267 & 1 & 23.267 & 249.275 & $.000 \mathrm{~b}$ \\
\cline { 2 - 5 } & Residual & 28.188 & 302 & 0.093 & & \\
\cline { 2 - 4 } & \multicolumn{7}{|c|}{ Total } & 51.455 & 303 & & & \\
\hline \multicolumn{7}{|c|}{ a. Dependent Variable: Individual Performance Review } \\
\hline \multicolumn{6}{|c|}{ b. Predictors: (Constant), Corporate Communication } \\
\hline
\end{tabular}

Table 2: Impact of ICC on Job Performance Public Telecom Sector Organizations

\begin{tabular}{|c|c|c|c|c|}
\hline \multicolumn{5}{|c|}{ Model Summary } \\
\hline Model & $\mathrm{R}$ & $\begin{array}{c}\mathrm{R} \\
\text { Square }\end{array}$ & $\begin{array}{c}\text { Adjusted R } \\
\text { Square }\end{array}$ & $\begin{array}{c}\text { Std. Error of the } \\
\text { Estimate }\end{array}$ \\
\hline 1 & $.503^{\mathrm{a}}$ & 0.254 & 0.251 & 0.55656 \\
\hline a. & Predictors: (Constant), Corporate Comm. \\
\hline
\end{tabular}

\begin{tabular}{|c|c|c|c|c|c|c|}
\hline \multicolumn{7}{|c|}{ ANOVAa } \\
\hline \multicolumn{2}{|c|}{ Model } & $\begin{array}{c}\text { Sum of } \\
\text { Squares }\end{array}$ & df & $\begin{array}{c}\text { Mean } \\
\text { Square }\end{array}$ & F & Sig. \\
\hline \multirow{3}{*}{1} & Regression & 31.454 & 1 & 31.454 & 101.542 & $.000 \mathrm{~b}$ \\
\cline { 2 - 5 } & Residual & 92.619 & 299 & 0.310 & & \\
\cline { 2 - 4 } & Total & 124.072 & 300 & & & \\
\hline \multicolumn{7}{|c|}{ a. Dependent Variable: Individual Performance Review } \\
\hline \multicolumn{6}{|c|}{ b. Predictors: (Constant), Corporate Communication } \\
\hline
\end{tabular}

The null hypothesis is not accepted the results of the regression analysis indicate that there is a significant impact of overall ICC on job performance in public sector telecom organizations at $\mathrm{F}=101.542 ; \mathrm{p}=.000$, and in the private sector at $\mathrm{F}=249.275 ; \mathrm{p}=.000$.
$\mathrm{H} 4_{0}$ : There is no significant difference in the impact of internal corporate communication satisfaction in predicting job performance in public and private telecom sector organizations.

The null hypothesis is not accepted the results of the regression analysis indicate that there is a significant difference in the impact of ICC in predicting job performance in the public and private sector telecom organization. A stronger impact being observed on private sector telecom organizations with $\mathrm{F}=249.275$; $\mathrm{p}=.000$ as compared to public sector with $\mathrm{F}=101.542 ; \mathrm{p}=.000$. In private telecom sector ICC can explain $45 \%$ of the variance of the dependent variable and in public sector ICC can explain $25.1 \%$ of variance of the dependent variable.

$\mathrm{H} 5_{0}$ : There is no significant difference in the impact of individual dimensions of internal corporate communication in predicting job performance in public and private telecom sector organization.

Table 3: Impact of ICC dimensions on job performance in public and private telecom organizations

\begin{tabular}{|l|c|c|c|c|c|}
\hline $\begin{array}{c}\text { S. } \\
\text { No }\end{array}$ & Items & Public Sector & $\Delta R^{2}$ & Private Sector & $\Delta R^{2}$ \\
\hline 1. & $\mathrm{SC}$ & $\mathrm{F}=103.549 ; \mathrm{p}=.000$ & .255 & $\mathrm{~F}=348.791 ; \mathrm{p}=.000$ & .534 \\
\hline 2. & Sb.C & $\mathrm{F}=32.085 ; \mathrm{p}=.000$ & .094 & $\mathrm{~F}=76.562 ; \mathrm{p}=.000$ & .200 \\
\hline 3. & $\mathrm{CC}$ & $\mathrm{F}=68.825 ; \mathrm{p}=.000$ & .184 & $\mathrm{~F}=105.318 ; \mathrm{p}=.000$ & .256 \\
\hline 4. & OI & $\mathrm{F}=88.432 ; \mathrm{p}=.000$ & .226 & $\mathrm{~F}=173.931 ; \mathrm{p}=.000$ & .363 \\
\hline 5. & MQ & $\mathrm{F}=30.731 ; \mathrm{p}=.000$ & .090 & $\mathrm{~F}=33.522 ; \mathrm{p}=.000$ & .097 \\
\hline 6. & $\mathrm{HC}$ & $\mathrm{F}=28.721 ; \mathrm{p}=.000$ & .085 & $\mathrm{~F}=65.522 ; \mathrm{p}=.000$ & .176 \\
\hline 7. & OP & $\mathrm{F}=80.345 ; \mathrm{p}=.000$ & .209 & $\mathrm{~F}=224.257 ; \mathrm{p}=.000$ & .424 \\
\hline 8. & PF & $\mathrm{F}=8.984 ; \mathrm{p}=.000$ & .026 & $\mathrm{~F}=36.611 ; \mathrm{p}=.000$ & .105 \\
\hline 9. & TMC & $\mathrm{F}=37.400 ; \mathrm{p}=.000$ & .108 & $\mathrm{~F}=86.171 ; \mathrm{p}=.000$ & .219 \\
\hline
\end{tabular}

The null hypothesis is not accepted, the results indicate that there is a significant difference in the impact of individual dimensions of ICC in predicting job performance in public and private sector telecom organizations. In private sector telecom organizations supervisory communication can explain $53.4 \%$ of the variance in job performance, followed by organizational perspective $42.4 \%$, organizational integration $36.3 \%$, communication climate $25.6 \%$ and top management communication 21.95. In public sector telecom organizations ICC does not seem to have a very strong impact in predicting job performance with supervisory communication explaining $25.5 \%$ variance followed by organizational integration $22.6 \%$, organizational perspective $20.9 \%$ and communication climate can explain $18.4 \%$ of the variance in job performance.

\section{Discussion}

The findings of the study reports a significant impact of ICC on employee performance and is in consistent with the studies undertaken by Jain (1973), Hellweg \& Phillips (1980), Downs \&Hain (1982), Camden \& Witt (1983), Snyder \& Morris (1984), Papa \& Tracy, (1987), Jo \& Shim (2005), Watson Wyatt study (2005/2006), Chuang and Hsieh, (2009), Agarwal, (2006), Giri\& Kumar (2010), Udegbe et al., (2012). Findings of the study consistent with previous findings reported by Tubbs \&Hain (1979) 


\section{International Journal of Science and Research (IJSR) \\ ISSN (Online): 2319-7064}

Index Copernicus Value (2015): 78.96 | Impact Factor (2015): 6.391

supervisory communication has a strong impact on job performance. It is in agreement with the findings with the studies undertaken by Ebren (2006), Murthy \& Guthrie (2013), Kumar \& Pansari (2014) organizational integration has a strong relationship with employee job performance. The findings are consistent with that of Jeavons (1994), Mullane (2002), Ridder (2004), McKenna (2012), Jurišová\&Durkova (2012), Rho et al. (2015) that organizational perspective has a strong relationship with job performance. The study also shares its findings with studies undertaken by Jain (1973), Pincus (1986), Clampitt \& Downs, (1993), Hargie et al., (2002), communication climate has a strong relationship with job performance. The study is not in consistent with the findings by Pettit et al., and reports supervisory communication, organizational integration, organizational perspective, communication climate and top management communication to be strong predictors of employee performance (Pettit et al., (1997).

\section{Conclusion}

- The perspective of organizations towards Internal Corporate Communication has changed slowly over the years but its importance has not been evaluated sufficiently in terms of affecting the job performance even today.

- Higher levels of job performances are reported in public telecom sector organizations as compared to private sector telecom organization.

- Previous (Extant) literature emphasizes the importance of lateral communication, personal feedback, supervisory communication, communication climate as highly crucial for enhancing job performance but in the present study organizational integration and organizational perspective have come out to be the two very important differentiating dimensions of ICC satisfaction influencing the job performance both in public and private sector telecom organizations.

\section{Limitations}

A bigger sample would have been more appropriate for aggregating the results of the study. The social and ethnic diversity of the area might also affect the study.

\section{Recommendations}

- The organizations should focus on disseminating information with employees about their immediate work environment, communication with more clarity in the vision, mission and objectives so as to enhance the levels of alignment of individual gaols with organizational objective and in turn enhance employee performance.

- The leader managers should develop a communication climate that shall enable the employees to communicate freely with their superiors, and top management without creating hierarchical barriers.

- The ICC departments of public and private sector firms can utilize this study in creating different ICC programs with reference to the findings of the study.
- In further scope the scholars can further build upon the reasons for this shift in information needs of the employees.

- The changes that need to be incorporated in the ICC programs with this change in information needs and its impact on their satisfaction with the ICC programs, their job satisfaction levels and their commitment and loyalty towards their employing firm.

\section{References}

[1] Agarwal, A. (2006). Email Etiquette: 10 Tips for Better Email Communication. Digital InspirationTechnology, à

[2] Ahmad, A. H. (2006). Auditing Communication Satisfaction among Academic Staff: An Approach to Managing Academic Excellence,The Business Review, Vol. 5(1), 330-333.

[3] Anderson, J., \& Level, D. A. (1980). The Impact of Certain Types of Downward Communication on Job Performance. Journal of Business Communication, Vol. 17, 51-59.

[4] Barney, J. B., \& Wright, P. M. (1998). On Becoming a Strategic Partner: The Role of Human Resources in Gaining Competitive Advantage. Human Resource Management, Vol. 37(1), 31

[5] Camden, C, \& Witt, J. (1983). Manager communicative style and productivity: A Study of Female and Male Managers. International Joumal of Women's Studies, Vol. 6, 258-269.

[6] Chuang and Hsieh, (2009). An Integrated Process Model of Communication Satisfaction and Organizational Outcomes.Social Behavior and Personality, Vol. 37(6), 825-834.

[7] Clampitt, P. G., \& Downs, C. W. (1993). Employee Perceptions of the Relationship between Communication and Productivity: A Field Study. Journal of Business Communication, 30(1), 5-28

[8] De Chernatony, L. and Horn, S.S. (2003). The Criteria for Successful Services Brands. European Journal of Marketing, Vol. 37(7), 1095-1118.

[9] De Ridder, J. (2003). Organisational communication and supportive employees. Human Resource Management Journal, Vol. 4(4), 1-10.

[10] Dolphin, R.A. (2005). Internal Communication: Today's Strategic Imperative. Journal of Marketing Communications, Vol. 11(3), 171-190.

[11] Domenec, F. (2012). The greening of the annual letters published by Exxon, Chevron and BP between 2003 and 2009. Journal of Communication Management, Vol. 16(3), 296-311.

[12] Downey, H. K., Hellriegel, D., \& Slocum, J. W., Jr. (1975). Congruence between individual needs, organizational climate, job satisfaction and performance. Academy of Management Journal, 18, 149-155

[13] Downs, C. W. (1994). Communication satisfaction questionnaire. In R. B. Rubin, P. Palmgreen, \& H. E. Sypher (Eds.), Communication research measures: A sourcebook (pp. 114-119). NY: Guilford.

\section{Future Scope}




\section{International Journal of Science and Research (IJSR) \\ ISSN (Online): 2319-7064}

Index Copernicus Value (2015): 78.96 | Impact Factor (2015): 6.391

[14] Downs, C. W., \& Adrian, A. D. (2004). Assessing organizational communication: Strategic communication audits. London: Guilford.

[15] Downs, C. W., \&Hain, T. (1982). Communication and productivity. In M. Burgoon (Ed.), Communication yearbook 5 (pp. 435-471). New Brunswick, NJ: IVansaction Books.

[16] Downs, C. W., \&Hain. T. (1981). Productivity and communication. In M. Burgoon (Ed.) Communication yearbook 5 (pp. 435453). New Brunswick, NJ: Transaction.

[17] Downs, C. W., \&Moscinski, P. (1979). A survey of appraisal processes and training in large corporations. Paper presented at the annual meeting of the Academy of Management, Atlanta.

[18] Downs, C. W., Hazen, M., Quiggens, J., \& Medley, J. (1973). An empirical and theoretical investigation of communication satisfaction. Paper presented at the annual meeting of the Speech Communication Association, New York City.

[19] Ebren, F. (2006). Impact of Integrated Marketing Communications Programs in Enhancing Manager and Employee Performance. Human And Economic Resources Proceedings Book,

[20] Edwards, L. (2009) 'Symbolic power and public relations practice: locating individual practitioners in their social context', Journal of Public Relations Research, Vol. 21(3), 251-272.

[21] Fay, M.J. (2011) 'Informal communication of coworkers: a thematic analysis of messages',Qualitative Research in Organizations and Management: An International Journal, Vol. 6(3), 212-229.

[22] Francis, D. (1989). Organisational communication. United Kingdom: Gower.

[23] Giri, V. N., \&Pavan Kumar, B. (2010). Assessing the impact of organizational communication on job satisfaction and job performance. Psychological Studies, Vol. 55(2), 137-143.

[24] Goodman, S. A. \&Svyantek, D. J. (1999). Personorganization fit and contextual performance: Do shared values matter. Journal of Vocational Behavior, 55, 254-275.

[25] Gratton, L. (2008). Counterpoint. People \& Strategy, Vol. 31(3), 9.

[26] Gray, J., \& Laidlaw, H. (2004). Improving the measurement of communication satisfaction. Management Communication Quarterly, Vol. 17(3), 425-448.

[27] Gray, J., Laidlaw, H. (2002). Flexible Work Arrangements and Organisational Communication: An Australian Retail Experience. Working Paper. Monash University Vol. 45(2), 2-16.

[28] Grunig, J. E. (ed.) (1992). Excellence in public relations and communication management. Hillsdale, NJ: Lawrence Erlbaum.

[29] Hargie, O., Dickson, D., \&Tourish, D. (2000). Communication in management. Aldershot, UK: Gower.

[30] Hargie, O., Tourish, D., \& Wilson, N. (2002). Communication audits and the effects of increased information: A follow-up study. The Journal of Business Communication, Vol. 39(4), 414-436.
[31] Hellweg, S. A., \& Phillips, S. L. (1980). Communication and Productivity in Organizations: A State-of-the-Art Review in Proceedings of the $40^{\text {th }}$ Annual Academy of Management Conference, Detroit, Michigan, 188-192.

[32] Hoben, K., Varley, R., and Cox, R. (2007), Clinical Reasoning Skills of Speech and Language Therapy Students", International Journal of Language \& Communication Disorders, Vol. 42(1),123-135.

[33] Jain, H. C. (1973). Supervisory communication and performance in urban hospitals. The Journal of Communication, Vol. 23, 103-117.

[34] Jeavons, T. H. (1994). When the bottom line is faithfulness: Management of Christian service organizations: Indiana University Press.

[35] Jo, S. and Shim, Y. (2004), Media or Personal Relations? Exploring Media Relations Dimensions in South Korea, Journalism and Mass Communication Quarterly, Vol. 81(2), 292-306.

[36] John D. Pettit, Jose R. Goris, Bobby C. Vaught. (1997). "An Examination of Organizational Communication as a Moderator of the Relationship between Job Performance and Job Satisfaction" The Journal of Business Communication, Vol. 34(1), 8198.

[37] Jurišová, V., \&Ďurková, K. (2012). CSR communication and its impact on corporate image. Review of Applied Socio-Economic Research, Vol. 4(2), 145-149.

[38] Kekelis, L.S., and Andersen, E.S. (1984). Family Communication Styles and Language Development, Journal of Visual Impairment \& Blindness, Vol. 78(2), 54-65.

[39] Kumar, V., \& Pansari, A. (2014). The Construct, Measurement, and Impact of Employee Engagement: A Marketing Perspective. Customer Needs and Solutions, Vol. 1(1), 52-67.

[40] McKenna, E. F. (2012). Business psychology and organisational behaviour: AStudent's Handbook: Psychology Press.

[41] McKenzie, K. L. (2015). The Relationship between Organizational Communication and Campus Climate as an Indicator of Organizational Effectiveness (Doctoral dissertation, Indiana University of Pennsylvania).

[42] Mullane, J. V. (2002). The Mission Statement is a Strategic Tool: When Used Properly. Management Decision, Vol. 40(5), 448-455.

[43] Mung'ora, M. W., Cheruiyot, P. K., \&Kwasira, J., (2014), Assessment Of Strategic Relationship Between Organizational Internal Communication And Employees' performance: A Case Of Commercial Banks In Nakuru County, Kenya.

[44] Murthy, V., \& Guthrie, J. (2013). Accounting for Workplace Flexibility: Internal Communication in an Australian Financial Institution. Accounting Research Journal, Vol. 26(2), 109-129.

[45] Nadarajah, R. (1992). Try thinking backwards. Total Quality Management Journal, Vol. 4(3), 161-3.

[46] Papa. M. J., \& Tracy, K. (1987). Communicative Indices of Employee Performance with New Technology. Paper presented at the annual meeting of 


\section{International Journal of Science and Research (IJSR) \\ ISSN (Online): 2319-7064 \\ Index Copernicus Value (2015): 78.96 | Impact Factor (2015): 6.391}

the International Communication Association, Montreal, Canada.

[47] Pincus, J. D. (1986). Communication Satisfaction, Job Satisfaction, and Job Performance. Human Communication Research, Vol. 12(3), 395-419.

[48] Postmes, T., Tanis, M., \& de Wit, B. (2001). Communication and Commitment in Organisations: A Social Identity Approach. Group Processes and Intergroup Relations, Vol. 4(3), 207-226.

[49] Rho, E., Yun, T., \& Lee, K. (2015). Does Organizational Image Matter? Image, Identification, and Employee Behaviors in Public and Non-profit Organizations. Public Administration Review, Vol. 75(3), 421-431.

[50] Ridder, J. A. (2004). Organisational communication and supportive employees. Human Resource Management Journal, Vol. 14(3), 20-30.

[51] Rodwell, J. J., Kienzle, R. \&Shadur, M. A. (1998). The relationships among work-related perceptions, employee attitudes, and employee performance: the integral role of communication. Human Resource Management, Vol. 37(3 and 4), 277-293.

[52] Sarojkoul, (2009). Communication structure of the public sector in India: an empirical analysis. Corporate Communications: An International Journal, Vol. 14(3), 320-332.

[53] Smidts, A., Pruyn, A. and Riel, V. (2001) 'The impact of employee communication and perceived external prestige on organizational identification', Academy of Management Journal, Vol. 49(5),1051-1062.

[54] Snyder, R. A., \& Morris, J. H. (1984). Organizational communication and performance. Journal of Applied Psychology, 69, 461-465.

[55] Thite, M. (2004) Managing People in the New Economy: Targeted HR Practices that Persuade People to Unlock their Knowledge Power, Response Books, New Delhi.

[56] Tubbs, S. L., \&Hain, T. (1979). Managerial communication and its relationship to total organizational effectiveness. Paper presented to the Academy of Management. VROOM, V. H. (1964). Work and motivation. New York John Wiley.

[57] Udegbe, S. E., Udegbe, M. I., Ogundipe, K. A., Ganiyat, A. O., \&Rashdidat, K. (2012). Impact of business communication on organizational performance in Nigerian companies. Australian Journal of Business and Management Research, Vol. 2(1), 16.

[58] Van Riel, C.B.M. (1995). Principles of Corporate Communication, Prentice-Hall, Englewood Cliffs, NL.

[59] Watson Wyatt study: Executive Summary: Effective Communication: A Leading Indicator of Financial Performance-2005/2006 Communication ROI study: retrieved 2008.02.10at http://www.watsonwyatt.com/research/resrender.asp?i $\mathrm{d}=\mathrm{w}-868$ \&page $=1$

[60] Welch, M. and Jackson, P.R. (2007). Rethinking internal communication: a stakeholder approach. Corporate Communications: An International Journal, Vol. 12(2), 177-198.

[61] Zimmermann, J. A. M., Stevens, B. W. (2006). The use of performance measurement in South Carolina nonprofits. Non-profit Management and Leadership, 16,315-327.

[62] Zwijze-Koning, K., \&de Jong, M. D. T. (2007). Evaluating the communication satisfaction questionnaire as acommunication audit tool. Management Communication Quarterly, 20(3),261282 